\title{
Synthesis and Biological Assays of a Peptide from a Tuberculin-Active Protein
}

\author{
JAROSLAV SAVRDA \\ Service de la Tuberculose, Institut Pasteur, 75 Paris, France
}

\begin{abstract}
The heptapeptide Asn-Gly-Ser-Gln-Met-Arg-Leu, part of a tuberculin-active intracellular mycobacterial protein and described in the literature as having residual tuberculin activity, has been synthesized. Biological assays of the synthetic peptide showed it to be recognized as an antigen of mycobacterial origin by its ability to elicit an early allergic reaction in Mycobacterium bovis BCG-infected mice. The synthetic peptide was shown to be devoid of any tuberculin activity in BCG-infected mice and in skin tests on Mycobacterium tuberculosis-sensitized guinea pigs. Purified protein derivative, the complex mixture of proteins of unknown composition which is excreted into the culture medium by $M$. tuberculosis and is in wide use as a tuberculin-active preparation, was shown to weakly cross-react in radioimmunoassays with the synthetic heptapeptide when ${ }^{125} \mathrm{I}$ labeled heptapeptide and an anti-heptapeptide antiserum were used.
\end{abstract}

Purified protein derivative (PPD; 16), the partially purified form of tuberculin obtained from the products excreted into the culture medium by Mycobacterium tuberculosis, is in wide use as a tuberculin-active preparation. It is capable of eliciting a delayed-type allergic reaction when administered intracutaneously to humans or other animals sensitized with tubercle bacilli. This material is, however, a complex mixture of proteins (1) lacking specificity for the diagnosis of tuberculous infection or disease and is improper for the laboratory investigation of cellmediated immunological phenomena. Thus, subjects infected with unrelated mycobacteria may cross-react with PPD, although these crossreactions are usually less intense than those obtained in persons infected with tubercle bacilli (4). The lack of specificity of PPD may be related to the heterogeneous nature of this product and to the presence of antigens shared by the various mycobacterial species. Despite numerous attempts to purify and separate the constituents of PPD, none of the antigens making up PPD has yet been characterized, and the isolation of a monospecific tuberculin has not been achieved. The complexity of PPD, as well as the drastic conditions used for the preparation of this material $\left(120^{\circ} \mathrm{C} / 20 \mathrm{lb}\right.$ [ca. $9 \mathrm{~kg}$ ] for $\left.30 \mathrm{~min}\right)$, may account for this lack of success. Moreover, it is possible that single molecules may possess multiple determinants, some of which are shared with a number of molecules found in different species of mycobacteria. Thus, the isolation from human tubercle bacilli and the sequence determination by Kuwabara $(11,12)$ of a tuberculinactive protein, one of intracellular origin, is an important step in the elucidation of the nature of the tuberculin-type mycobacterial antigens. This protein is more potent than PPD and, according to published results (11), accounts for the total tuberculin activity found in the intracellular proteic content. After enzymatic digestion, a tryptic hexapeptide, Asn-Gly-Ser-GlnMet-Arg, was found to have residual tuberculin activity (12) in skin tests. This provided an opportunity to probe, by chemical synthesis, the nature of the determinant responsible for the delayed-type allergic reaction.

This study describes the synthesis of the heptapeptide Asn-Gly-Ser-Gln-Met-Arg-Leu and biological assays designed to test its antigenic activities. Furthermore, to ascertain the presence of Kuwabara's tuberculin-active protein (12) or of some of its fragments in common tuberculin-active preparations, antibodies have been raised against the synthetic heptapeptide; by using a radioimmunoassay procedure, the presence of this antigen was established in PPD.

\section{MATERIALS AND METHODS}

Abbreviations. The peptides Asn-Gly-Ser-GlnMet-Arg and Asn-Gly-Ser-Gln-Met-Arg-Leu will be referred to hereafter as the hexapeptide and the heptapeptide. The following abbreviations are used: BOC, $t$-butyloxycarbonyl; Bzl, benzyl; Tos, $p$-toluenesulfonyl; NB, p-nitrobenzyl; TFAOH, trifluoracetic acid.

Materials. Aminopeptidase $M$ and 1-ethyl-3(3dimethylaminopropyl)-carbodiimide hydrochloride were purchased from Sigma Chemical Co., trypsin (trypsin treated with tolylsulfonyl phenylalanyl chloromethyl ketone, $220 \mathrm{U} / \mathrm{mg}$ ) was from Worthington Biochemicals Corp., and $50 \%$ aqueous glutaraldehyde was from Eastman Kodak. Egg albumin grade B was 
obtained from Calbiochem, bovine serum albumin (BSA) was from Behringwerke AG, and Freund incomplete adjuvant was from Difco Laboratories. Bolton-Hunter reagent ${ }^{125}$ I-labeled 3-(4-hydroxyphenyl)propionic acid $N$-succinimidyl ester) was purchased from New England Nuclear Corp., and PPDneutre Pasteur was a generous gift from J. Augier. Sepharose-bound soybean trypsin inhibitor was prepared and generously given by $M$. Goldberg of the Pasteur Institute, and $\boldsymbol{N}$-acetyl-muramyl-L-alanyl-Disoglutamine was a generous gift from $P$. Lefrancier (Institut Choay, Paris, France). L-Glutamine p-nitrobenzyl ester hydrobromide was purchased from Bachem AG. All other L-amino acid derivatives as well as dicyclohexylcarbodiimide and 1-hydroxybenzotriazole were purchased from Fluka. Boron tris(trifluoracetate) and thioanisole were obtained from Aldrich Chemical Co., and Kieselgel 60 silica gel (230 mesh) was from E. Merck AG.

Experimental procedures for synthesis of the heptapeptide Asn-Gly-Ser-Gln-Met-Arg-Leu. (i) Silica gel thin-layer chromatography. Silica gel thin-layer chromatography was run in $n$-butanolacetic acid-water (3:1:1). Free amino functions were revealed with ninhydrin, and $N$-BOC-protected peptides were revealed by the chlorine-4,4'-tetramethyldiamine diphenylmethane procedure (18) or with ninhydrin after hydrochloric acid treatment of chromatograms.

(ii) BOC-Arg(To8)-Leu-OBzl (I). Dicyclohexylcarbodiimide $(2.26 \mathrm{~g}, 11 \mathrm{mmol})$ was added at $0^{\circ} \mathrm{C}$ to a dimethylformamide solution $(16 \mathrm{ml})$ containing $N^{\alpha}$. BOC- $\omega$-Tos-arginine $(4.71 \mathrm{~g}, 11 \mathrm{mmol})$, leucine benzyl ester $p$-tosylate $(5.90 \mathrm{~g}, 15 \mathrm{mmol}), N$-methyl morpholine (1.65 ml, $15 \mathrm{mmol})$, and 1-hydroxybenzotriazole $(3.0 \mathrm{~g}, 20 \mathrm{mmol})(9)$. After $1 \mathrm{~h}$ at $0^{\circ} \mathrm{C}$, the reaction mixture was left to stand at room temperature overnight; it was then filtered, diluted with ethyl acetate, and washed with 5\% aqueous sodium bicarbonate, 0.2 $M$ potassium hydrogen sulfate, and water. The organic solution was dried over magnesium sulfate and evaporated to a small volume, and the product was precipitated with $n$-hexane. The crude product was dissolved in chloroform and chromatographed on a silica gel column in the same solvent. A fast-moving contaminant was first eluted with chloroform, and then the chromatographically pure product was washed out with chloroform-methanol (20:1). The collected fractions were evaporated to dryness, and the resulting oil was dissolved in a small volume of ethyl acetate and added with stirring to $n$-hexane. The protected dipeptide precipitated as a fine powder. The yield was 4.74 g (68\%) (mp $85^{\circ} \mathrm{C}$ after sintering [uncorrected]; $[\alpha]_{\mathrm{D}}^{22}$ $=-22.3 \pm 0.5^{\circ}[c=3.0$, methanol $]$ ). Analysis: calculated for $\mathrm{C}_{31} \mathrm{H}_{45} \mathrm{~N}_{5} \mathrm{O}_{7} \mathrm{~S}$ : $\mathrm{C}, 58.93 ; \mathrm{H}, 7.18 ; \mathrm{N}, 11.09$. Found: C, 58.55; H, 7.22; N, 11.08.

(iii) H-Arg(Tos)-Leu-OBzl hydrochloride (II). Cold $2 \mathrm{~N}$ hydrogen chloride in ethyl acetate $(42 \mathrm{ml})$ was added to an ethyl acetate solution $(15 \mathrm{ml})$ of peptide I (4.10 g, $6.5 \mathrm{mmol})$, and the reaction mixture was stirred at $0^{\circ} \mathrm{C}$ for $30 \mathrm{~min}$ and at room temperature for $1 \mathrm{~h}$. On addition of ether the precipitate was washed with ether and dried. The yield was $3.83 \mathrm{~g}$ (97\%) (mp 79 to $82^{\circ} \mathrm{C}$ [uncorrected]; $[\alpha]_{\mathrm{D}}^{22}=-8.8 \pm$ $0.5^{\circ}[c=2.0$, dimethylformamide $]$ ). Analysis: calcu- lated for $\mathrm{C}_{26} \mathrm{H}_{37} \mathrm{~N}_{5} \mathrm{O}_{5} \mathrm{~S}$, 2HCl: $\mathrm{C}, 51.65 ; \mathrm{H}, 6.50 ; \mathrm{N}$, 11.58. Found: C, 51.78; H, 6.34; N, 11.58.

(iv) BOC-Met-Arg(To8)-Leu-OBzl (III). A solution of $N^{\alpha}$-BOC-methionine $(1.58 \mathrm{~g}, 6.35 \mathrm{mmol})$ and $N$-methyl morpholine $(0.70 \mathrm{ml}, 6.35 \mathrm{mmol})$ in peroxide-free dry tetrahydrofuran $(30 \mathrm{ml})$ was cooled to $-15^{\circ} \mathrm{C}$, and ethyl chloroformate $(0.61 \mathrm{ml}, 6.35 \mathrm{mmol})$ was added. After the solution was stirred for $2 \mathrm{~min}$ under a calcium chloride guard tube, a cold suspension of peptide II $(3.83 \mathrm{~g}, 6.35 \mathrm{mmol})$ and $N$-methyl morpholine $(0.70 \mathrm{ml}, 6.35 \mathrm{mmol})$ in dry tetrahydrofuran $(30 \mathrm{ml})$ was added; the reaction mixture was further stirred at $-10^{\circ} \mathrm{C}$ for $30 \mathrm{~min}$ and then at room temperature for $2 \mathrm{~h}$. The reaction mixture was diluted with ethyl acetate and worked up and chromatographed as described for the preparation of peptide I. The yield was $3.22 \mathrm{~g} \mathrm{(66 \% )} \mathrm{(indefinite} \mathrm{mp} 80$ to $95^{\circ} \mathrm{C}$ [uncorrected $][\alpha]_{\mathrm{D}}^{22}=-21.2 \pm 0.5^{\circ}[c=2.0$, dimethylformamide]). Analysis: calculated for $\mathrm{C}_{36} \mathrm{H}_{54} \mathrm{~N}_{6} \mathrm{O}_{8} \mathrm{~S}_{2}$ : $\mathrm{C}$, 56.67; H, 7.13; N, 11.02; S, 8.40. Found: C, 56.88; H, 7.01; N, 10.77; S, 8.44

(v) BOC-Ser(Bzl)-Gln-ONB (IV). $N^{\alpha}$-BOC- $\beta$-Bzlserine $(3.40 \mathrm{~g}, 11.5 \mathrm{mmol})$ and glutamine NB ester hydrobromide $(4.16 \mathrm{~g}, 11.5 \mathrm{mmol})$ were coupled by the mixed anhydride procedure as described for the preparation of tripeptide III in a dimethylformamide-tetrahydrofuran (1:1) mixture (40 ml). After the usual workup, the product crystallized out from a concentrated ethyl acetate solution and was washed with ether and dried. The yield was $5.53 \mathrm{~g}(86 \%) \mathrm{mp} 154$ to $156^{\circ} \mathrm{C}$ [uncorrected]; $[\alpha]_{\mathrm{D}}^{22}=-4.6 \pm 0.5^{\circ}[c=2.0$, dimethylformamide]). Analysis: calculated for $\mathrm{C}_{27} \mathrm{H}_{34} \mathrm{~N}_{4} \mathrm{O}_{9}$ : $\mathrm{C}$, 58.06; H, 6.14; N, 10.03. Found: C, 58.38; H, 6.11; N, 10.06 .

(vi) BOC-Asn-Gly-OBzl (V). $N^{\alpha}$-BOC-asparagine $(4.64 \mathrm{~g}, 20 \mathrm{mmol})$ and glycine benzyl ester tosylate $(6.75 \mathrm{~g}, 20 \mathrm{mmol})$ were coupled according to the procedure described for the preparation of peptide I. The reaction mixture was diluted with ethyl acetate and worked up as usual except that the 5\% aqueous sodium bicarbonate wash was kept to a minimum. The product was precipitated from a concentrated ethyl acetate solution by addition of ether and was repeatedly triturated in fresh ether. The protected dipeptide crystallized from methanol on addition of water. The yield was $5.12 \mathrm{~g} \mathrm{(67 \% )} \mathrm{(mp} 135$ to $137^{\circ} \mathrm{C}$ [uncorrected] $[\alpha]_{\mathrm{D}}^{22}=-10.4 \pm 0.5^{\circ}[c=3.0$, dimethylformamide $]$ ). Analysis: calculated for $\mathrm{C}_{18} \mathrm{H}_{25} \mathrm{~N}_{3} \mathrm{O}_{6}: \mathrm{C}, 56.98 ; \mathrm{H}, 6.64$; $\mathrm{N}$, 11.08. Found: $\mathrm{C}, 57.07 ; \mathrm{H}, 6.60 ; \mathrm{N}, \mathbf{1 1 . 0 7}$.

(vii) BOC-Aon-Gly-OH (VI). The protected dipeptide (V) (3.31 g, $8.75 \mathrm{mmol})$ was dissolved in ethanol $(100 \mathrm{ml})$ and submitted to catalytic hydrogenolysis in the presence of $10 \% \mathrm{Pd}-\mathrm{C}$. The filtered solution was evaporated to dryness, and the residual oil was triturated in ether. The dipeptide crystallized out. The yield was $2.37 \mathrm{~g}$ (94\%) (mp 148 to $150^{\circ} \mathrm{C}$ [uncorrected]). Analysis: calculated for $\mathrm{C}_{11} \mathrm{H}_{19} \mathrm{~N}_{3} \mathrm{O}_{6}: \mathrm{C}, 45.67$; $H, 6.62 ; \mathrm{N}, 14.53$. Found: $C, 45.52 ; \mathrm{H}, 6.67 ; \mathrm{N}, 14.61$.

(viii) BOC-Asn-Gly-Ser(Bzl)-Gln-ONB (VII). The protected dipeptide (IV) $(5.2 \mathrm{~g}, 9.3 \mathrm{mmol})$ was dissolved in acetone $(180 \mathrm{ml})$ and was treated with 3 $\mathrm{N}$ hydrogen chloride in ethyl acetate $(180 \mathrm{ml})$ at $0^{\circ} \mathrm{C}$ for $30 \mathrm{~min}$ and at room temperature for $1 \mathrm{~h}$. The reaction mixture was concentrated at $30^{\circ} \mathrm{C}$ under vacuum to a small volume. On addition of ether the $\beta$ - 
benzyl ether of L-seryl-L-glutamine NB ester hydrochloride $\left(R_{f}, 0.51\right)$ was obtained in quantitative yield and was coupled to dipeptide VI $(2.7 \mathrm{~g}, 9.3 \mathrm{mmol})$ according to the procedure described for the preparation of peptide I. The reaction mixture was diluted with ethyl acetate and worked up as usual except that the aqueous 5\% sodium bicarbonate wash was kept to a minimum. The product precipitated from a concentrated ethyl acetate solution on addition of ether. The crude protected tetrapeptide was dissolved in hot ethanol and left to crystallize on cooling, it was then filtered and washed with cold ethanol and ether. The yield was $4.1 \mathrm{~g} \mathrm{(60 \% )} \mathrm{(mp} 189$ to $192^{\circ} \mathrm{C}$ [uncorrected] $[\alpha]_{\mathrm{D}}^{22}=-13.5 \pm 0.5^{\circ}[c=2.0$, dimethylformamide $]$ ). Analysis: calculated for $\mathrm{C}_{33} \mathrm{H}_{43} \mathrm{~N}_{7} \mathrm{O}_{12}: \mathrm{C}, 54.31 ; \mathrm{H}, 5.94$; $\mathrm{N}, 13.44$. Found: $\mathrm{C}, 54.34 ; \mathrm{H}, 6.05 ; \mathrm{N}, 13.39$.

(ix) BOC-Asn-Gly-Ser-Gln-OH (VIII). The tetrapeptide (VII) $(3.94 \mathrm{~g}, 5.4 \mathrm{mmol})$ was dissolved in methanol $(140 \mathrm{ml})$ and water $(10 \mathrm{ml})$ and was submitted to catalytic hydrogenolysis in the presence of $10 \%$ Pd-C. Hydrogenolysis was continued until the complete disappearance of a partially hydrogenolyzed tetrapeptide intermediate $\left(R_{f}, 0.48\right)$. The filtered reaction mixture was repeatedly evaporated under diminished pressure in the presence of ethanol. The fully hydrogenolyzed tetrapeptide $\left(R_{f}, 0.33\right)$ was obtained as a crystalline material (contaminated with a by-product of the reduction of the NB ester moiety $\left.\left[R_{f}, 0.55\right]\right)$ by trituration of the residual oil in ethyl acetate. Repeated extraction with warm ethanol and reprecipitation with ethyl acetate removed most of the contaminant to give a chromatographically pure product. The yield was $2.25 \mathrm{~g}(82 \%)\left(\mathrm{mp} 150\right.$ to $155^{\circ} \mathrm{C}$ [uncorrected] $[\alpha]_{\mathrm{D}}^{22}=-3.9 \pm 0.5^{\circ}[c=2.0$, dimethylformamide]). Analysis: calculated for $\mathrm{C}_{19} \mathrm{H}_{32} \mathrm{~N}_{6} \mathrm{O}_{10}: \mathrm{C}$, 45.24; H, 6.39; N, 16.66. Found: C, 44.52; H, 6.83; N, 15.56 .

(x) BOC-Asn-Gly-Ser-Gln-Met-Arg(Tos)-LeuOBzl (IX). The tripeptide (III) $(3.12 \mathrm{~g}, 4.1 \mathrm{mmol})$ was dissolved in TFAOH $(40 \mathrm{ml})$ at $20^{\circ} \mathrm{C}$ and left to stand for $30 \mathrm{~min}$. After evaporation to dryness at $20^{\circ} \mathrm{C}$ under reduced pressure, the L-methionyl-( $\omega$-tosyl)-L-arginyl$\mathrm{L}$-leucine benzyl ester trifluoracetate $(3.10 \mathrm{~g}, 4.0 \mathrm{mmol}$; $\boldsymbol{R}_{f}, 0.72$ ) was obtained as a solid by trituration of the residual oil in ether and was coupled to pentapeptide VIII $(2.02 \mathrm{~g}, 4.0 \mathrm{mmol})$ according to the procedure described for the preparation of peptide I. The reaction mixture was filtered free from dicyclohexyl urea, and the product was precipitated by addition of water. Two recrystallizations from ethanol removed the contaminating 1-hydroxybenzotriazole and gave an analytically pure protected heptapeptide. The yield was $2.84 \mathrm{~g}(62 \%) ;\left(\mathrm{mp} 197\right.$ to $199^{\circ} \mathrm{C}$ [uncorrected]; $[\alpha]_{\mathrm{D}}^{22}$, $=-17.3 \pm 0.5^{\circ}[c=2.0$, dimethylformamide]). Analysis: calculated for $\mathrm{C}_{50} \mathrm{H}_{76} \mathrm{~N}_{12} \mathrm{O}_{15} \mathrm{~S}_{2}$ : C, 52.25; H, 6.67; $\mathrm{N}, 14.62$. Found: $C, 51.71 ; \mathrm{H}, 6.76 ; \mathrm{N}, 14.49$. The amino acid analysis of an acid hydrolysate gave: Asp, 1.04; Gly, 0.96; Ser, 0.86; Glu, 1.02; Met, 0.89; Arg, 1.00; Leu, 1.00 .

(xi) H-Asn-Gly-Ser-Gln-Met-Arg-Leu-OH (X). (a) The protected heptapeptide (IX) $(575 \mathrm{mg}, 0.5$ mmol) was dissolved in TFAOH $(10 \mathrm{ml})$ and left to stand at room temperature. After $30 \mathrm{~min}$ the TFAOH was removed under reduced pressure, and the residual oil was dissolved in fresh TFAOH $(2 \mathrm{ml})$; after cooling to $0^{\circ} \mathrm{C}$, thioanisole $(3 \mathrm{ml}, 25 \mathrm{mmol})$ and $1 \mathrm{M}$ boron tris(trifluoracetate) in TFAOH $(30 \mathrm{ml})$ (14) were added, and the reaction mixture was stirred at room temperature for $1 \mathrm{~h}$. The solvent was evaporated under reduced pressure, and the residual oil was dissolved in water, repeatedly extracted with ethyl acetate, and chromatographed on a Bio-Rex 70 column ( $\mathrm{H}^{+}$form). Boric acid was washed out with water, and the product was eluted with a 0.5 to $2 \mathrm{M}$ acetic acid gradient. The peptide-containing fractions were evaporated to a small volume under reduced pressure, dissolved in water, and twice lyophilized. The yield was $164 \mathrm{mg}$ (38\%). Paper electrophoresis run according to the procedure described by Offord (13) gave a single ninhydrin- and Sakaguchi-positive spot with the expected electrophoretic mobility $(m=0.33)$. Paper electrophoresis at $\mathrm{pH} 1.9(40 \mathrm{~V} / \mathrm{cm}, 0.2 \mathrm{~mA} / \mathrm{cm}, 45 \mathrm{~min})$ gave a single spot migrating/towards the cathode $9 \mathrm{~cm}$. The amino acid analysis of an acid hydrolysate of the product gave: Asp, 1.01; Gly, 1.05; Ser, 0.85; Glu, 1.03; Met, 0.91; Arg, 1.02; Leu, 1.00. The amino acid analysis of an aminopeptidase $\mathbf{M}$ digest gave: Asn plus Gln, 1.93; Gly, 1.05; Ser, 0.99; Met, 1.00; Arg, not determined; Leu, 1.05 .

(b) The protected heptapeptide (IX) (172 mg, 0.1 mmol) was dissolved at $-70^{\circ} \mathrm{C}$ in hydrogen fluoride $(8 \mathrm{ml})(15)$ in the presence of anisole $(1 \mathrm{ml})$ and dimethylsulfide $(1 \mathrm{ml})$ and was left at $0^{\circ} \mathrm{C}$ for $1 \mathrm{~h}$. The hydrogen fluoride was removed under vacuum, the residue was dissolved in water, and the aqueous solution was extracted with ether and lyophilized. On paper electrophoresis this crude product behaved similarly to the material prepared in (a). At pH 6.5 the major component had an electrophoretic mobility of 0.33 (13) and was accompanied by two contaminants in trace amounts showing electrophoretic mobilities of 0.48 (ninhydrin and Sakaguchi positive) and -0.02 (ninhydrin positive and Sakaguchi negative).

Peptide fragments. The tetrapeptide Asn-GlySer-Gln and the pentapeptide Ser-Gln-Met-Arg-Leu were prepared from peptides VIII, IV, and III by procedures similar to those described for the synthesis of the heptapeptide $(\mathrm{X})$ and were not further characterized before use in radioimmunoassays.

Preparation of conjugates. (i) A 25-mg amount of BSA and $11 \mathrm{mg}$ of heptapeptide were dissolved in $3.5 \mathrm{ml}$ of $0.1 \mathrm{M}$ phosphate buffer ( $\mathrm{pH} 7.4)$, and $1.5 \mathrm{ml}$ of a $16 \mathrm{mM}$ aqueous glutaraldehyde solution was added. The reaction mixture was left to stand at room temperature overnight in the dark and then dialyzed first against $200 \mathrm{ml}$ of phosphate-buffered saline (PBS; $0.05 \mathrm{M}$ phosphate buffer [pH 7.4], $0.15 \mathrm{M}$ sodium chloride) for $16 \mathrm{~h}$ and then exhaustively against fresh PBS. The BSA-heptapeptide conjugate in PBS was kept in a freezer before use for immunization. The amount of heptapeptide coupled to BSA (18 mol of peptide per mol of BSA) was estimated by ninhydrin analysis after saponification (8) from the amount of free peptide in the first dialysate and from previous knowledge of the diffusion properties of the BSA and of the peptide.

(ii) A 25-mg amount of egg albumin and $6 \mathrm{mg}$ of heptapeptide were dissolved in $2.5 \mathrm{ml}$ of $0.1 \mathrm{M}$ phosphate buffer (pH 5.0), and $100 \mathrm{mg}$ of 1-ethyl-3(3-dimethylaminopropyl)carbodiimide hydrochloride in 2.5 
$\mathrm{ml}$ of the same buffer was added. The pH was kept at 5.0 with $0.5 \mathrm{~N}$ hydrochloric acid during the first few minutes, and the reaction mixture was left to stand at room temperature overnight. After dialysis against distilled water the aqueous solution was lyophilized. The heptapeptide content of the conjugate, estimated as above (i), was $90 \mu \mathrm{g}$ of peptide per $\mathrm{mg}$ of egg albumin.

Immunization procedure. Rabbits were immunized by multisite subcutaneous injections of $2 \mathrm{mg}$ of BSA-heptapeptide conjugate and $200 \mu \mathrm{g}$ of $N$-acetylmuramyl-L-alanyl-D-isoglutamine (5) in $0.5 \mathrm{ml}$ of PBS, dispersed in $0.5 \mathrm{ml}$ of Freund incomplete adjuvant. Each rabbit received three injections over a period of 2 weeks and booster injections every 2 months. Antisera were collected 10 days after injection and then collected every 2 weeks.

Preparation of ${ }^{125}$ I-labeled heptapeptide. A 10$\mu \mathrm{g}$ portion of the heptapeptide in $20 \mu \mathrm{l}$ of $0.1 \mathrm{M}$ phosphate buffer (pH 7.4) was added to $1 \mathrm{mCi}$ of Bolton-Hunter reagent (3) (specific activity, ca. 2,200 $\mathrm{Ci} / \mathrm{mmol}$ ); the reaction mixture was kept at $0^{\circ} \mathrm{C}$ for 1 $h$ and was developed on silica gel thin-layer chromatography in $n$-butanol-acetic acid-water (4:1:1). The immunoreactive radioactive band $\left(R_{f}, 0.40\right)$ was eluted with approximately $2 \mathrm{ml}$ of a water-methanol (1:1) mixture. This stock solution of labeled peptide $(430,000 \mathrm{cpm} / 10 \mu \mathrm{l})$ was kept at $<0^{\circ} \mathrm{C}$ before use.

Enzymatic digestions. Solutions, 1\%, of heptapeptide or PPD (PPD-neutre Pasteur) in $0.01 \mathrm{M}$ calcium chloride- $0.05 \mathrm{M}$ tris(hydroxymethyl)aminomethane buffer (pH 7.4) were digested with trypsin, with a protease-to-substrate final weight ratio of 1:50, at $30^{\circ} \mathrm{C}$ for $19 \mathrm{~h}$; trypsin was added in two portions. The hydrolysates were passed in a Pasteur pipette on Sepharose-bound soybean trypsin inhibitor and eluted with appropriate volumes of a $0.05 \mathrm{M}$ tris(hydroxymethyl)aminomethane buffer (pH 7.4), containing $0.15 \mathrm{M}$ sodium chloride, $0.1 \%$ sodium azide, and $0.5 \% \mathrm{BSA}$, to give stock solutions containing 160 $\mu \mathrm{g}$ of hydrolyzed substrate per $100 \mu \mathrm{l}$. These were diluted with the same buffer for radioimmunoassays. A sample of the tryptic digest of the heptapeptide (5 mg) was chromatographed on silica gel thin-layer plates. The bands, excluding leucine, corresponding to residual undigested heptapeptide and to the tryptic hexapeptide were eluted and subjected to acid hydrolysis. The amount of undigested peptide was estimated $(<1 \%)$ by the appearance of leucine on the chromatograms.

Radioimmunoassay procedure. Phosphate, 0.05 $\mathrm{M}$, or $0.05 \mathrm{M}$ tris(hydroxymethyl)aminomethane (pH 7.4), containing $0.15 \mathrm{M}$ sodium chloride, $0.1 \%$ sodium azide, and $0.5 \%$ BSA, was used as the buffer. To each test tube were added $200 \mu \mathrm{l}$ of buffer, $100 \mu \mathrm{l}$ of ${ }^{125} \mathrm{I}$ labeled heptapeptide (approximately $10,000 \mathrm{cpm}$ of stock solution diluted with buffer), $100 \mu \mathrm{l}$ of standards dissolved in buffer, and $100 \mu \mathrm{l}$ of antiserum diluted (1: 50,000 ) with buffer to give approximately $40 \%$ bound labeled heptapeptide in the absence of added unlabeled standard. The samples, assayed in duplicate, were incubated at $4^{\circ} \mathrm{C}$ for $24 \mathrm{~h}$. Bound and free antigens were then separated at $0^{\circ} \mathrm{C}$ by adding to each tube $10 \mu$ l of undiluted normal rabbit serum followed by $1 \mathrm{ml}$ of cold propanol. The tube contents were blended in a Vortex mixer and centrifuged at $4^{\circ} \mathrm{C}$ for $15 \mathrm{~min}$ at $3,000 \times \mathrm{g}$. The supernatant was removed and the pellets were counted in a gamma scintillation counter.

Tuberculin tests. (i) Tests on guinea pigs were carried out by J. Augier of the Tuberculin Unit, Pasteur Institute, Paris. Doses of 100, 20, and $4 \mu \mathrm{g}$ of the heptapeptide or of the BSA-heptapeptide conjugate in $100 \mu \mathrm{l}$ of PBS buffer containing Tween 80 were administered intradermally in the ventral side of guinea pigs sensitized 6 weeks before with $M$. tuberculosis strain Aoyama/B or $M$. bovis strain BCGPasteur. The appearance of delayed-type tuberculin reaction was looked for 24 and $48 \mathrm{~h}$ after injection.

(ii) Tests on BCG-infected mice were carried out by P. Lagrange, Laboratoire d'Immunologie du BCG, Pasteur Institute, Paris. A 1- to $1,000-\mu \mathrm{g}$ portion of heptapeptide in PBS was injected in the footpads of mice, and the swelling was measured regularly thereafter.

\section{RESULTS}

Peptide synthesis. The heptapeptide AsnGly-Ser-Gln-Met-Arg-Leu was synthesized as described in Materials and Methods. It was thought advisable to retain in the synthetic peptide the C-terminal leucine residue (part of the original protein) to leave open the possibility of BSA-heptapeptide conjugate preparation by coupling of the peptide to the carrier protein through the peptide's $\alpha$-carboxylic acid function. It was thought that such a coupling, mediated by a carbodiimide, could lead, in the case of a hexapeptide with a C-terminal arginine, to important loss of material through lactamization involving the guanidine function of arginine (2) or possible cyclization of the hexapeptide or both. The choice of protecting groups, masking temporarily $\alpha$-amino, $\alpha$-carboxylic acid, $\beta$-hydroxyl, and $\omega$-guanidine functions, was largely dictated by the amino acid composition of the peptide. In particular, the side chain of arginine was protected with the tosyl group removable by hydrogen fluoride (15) or by boron tris(trifluoracetate) (14), which proved in this case to be the more preferable procedure, because other possible protecting groups could not be removed without risk by catalytic hydrogenolysis in the presence of methionine (7). Catalytic hydrogenation in liquid ammonia, advocated $(10)$ in the case of peptides containing sulfur, was avoided because of the known (6) and observed instability of the Asn-Gly sequence in the presence of base. Because of this instability, proof of the integrity of the asparagine (and glutamine) residues in the final, Sakaguchi-positive, free peptide was given by the amino acid analysis of an aminopeptidase $M$ digest of the peptide. This analysis, as well as that of a $6 \mathrm{~N}$ hydrochloric acid hydrolysate of the peptide, 
showed that oxidation of methionine did not occur to any significant extent and showed the correct composition of the synthetic product. The removal of the protective groups from the synthetic heptapeptide required the use of acid conditions: treatment with either liquid hydrogen fluoride or boron tris(trifluoracetate) in TFAOH (14). Under these conditions an $\mathrm{N} \rightarrow 0$ acyl shift of the $\mathrm{N}$-terminal asparaginyl-glycine dipeptide was theoretically possible (17), with simultaneous acylation of the free serine alcoholic function and liberation of a new $\alpha$-amino group. That this side reaction did not occur to any significant extent was shown by the correct electrophoretic mobility of the final product at pH 6.5 according to the procedure of Offord (13).

Tuberculin activity of the heptapeptide and its BSA conjugate. No tuberculin-positive skin reaction could be detected in guinea pigs sensitized with BCG. Because the tuberculinactive protein sequenced by Kuwabara was isolated from the Aoyama/B strain of the tubercle bacillus $(11,12)$, guinea pigs were sensitized with this strain. In these animals, the intradermal injections of various amounts of the peptide (maximum dose tested, $100 \mu \mathrm{g}$ of antigen per 100 $\mu \mathrm{l}$ of PBS) did not elicit a tuberculin reaction. Likewise, the BSA-heptapeptide conjugate did not elicit a tuberculin reaction. On the other hand, the injection of $10 \mathrm{U}$ of PPD to these animals elicited, on the average, a skin reaction of $17 \mathrm{~mm}$.

When BCG-infected mice were injected in the footpads with $1,000 \mu \mathrm{g}$ of heptapeptide, an early allergic, Arthus-type reaction could be observed within $4 \mathrm{~h}$. No delayed tuberculin-type reaction developed within 24 to $48 \mathrm{~h}$.

Preparation of heptapeptide-specific antibodies. Because the synthetic peptide did not: elicit a tuberculin reaction in sensitized guinea. pigs, antibodies directed against it were prepared: to verify whether they would react with some. antigen in PPD. The antibodies were prepared in rabbits by injecting the BSA-heptapeptide conjugate and using $N$-acetyl-muramyl-Lalanyl-D-isoglutamine (5) as adjuvant instead of Freund complete adjuvant (killed tubercle bacilli in mineral oil) to avoid the presence of undesired antigens of bacterial origin during the immunization procedure. The antisera thus prepared reacted with BSA (ring test, Ouchterlony immunodiffusion test) but not with egg albumin. Antibodies precipitating the heptapeptide or the egg albumin-heptapeptide conjugate were not detected by using classical precipitin reactions (ring test, immunodiffusion). However, as shown below, antibodies that specifically recognized the heptapeptide were demonstrated by using a radioimmunoassay procedure.
Radioimmunoassay evidence of the presence in PPD of an antigen cross-reacting with the heptapeptide. An antiserum capable of binding $40 \%$ of a 10,000 -cpm dose of ${ }^{125} \mathrm{I}$-labeled heptapeptide at a 1:50,000 dilution and showing a good affinity for this antigen was selected for radioimmunoassays. In Fig. 1 are depicted the effects of the addition to the radioimmunoassay of increasing amounts of unlabeled heptapeptide and of its fragments, and in Fig. 2 are shown the effects of the addition of PPD, trypsin-digested PPD, and the hexapeptide obtained by tryptic digestion of the parent synthetic heptapeptide. Approximately $900 \mathrm{pg}$ of heptapeptide or the C-terminal pentapeptide was required to displace half of the label, whereas the $\mathrm{N}$-terminal tetrapeptide had no effect in the range studied. The same level of displacement could be attained only after the addition of approximately $15 \mathrm{ng}$ of hexapeptide, $36 \mu \mathrm{g}$ of PPD, and $160 \mu \mathrm{g}$ of trypsin-digested PPD. Consequently, these results showed that the protein isolated by Kuwabara, or some of its fragments, was present in PPD.

\section{DISCUSSION}

The heptapeptide Asn-Gly-Ser-Gln-Met-ArgLeu, which includes the hexapeptide sequence described (12) as tuberculin active, was found to be devoid of any tuberculin activity in skin tests performed on BCG- or Aoyama/B-sensitized guinea pigs. Because a small peptide might diffuse too rapidly to react with immunocompetent lymphocytes in a restricted area, similar skin tests were performed with the BSA-heptapeptide conjugate. These were found to be equally negative. Thus, the heptapeptide sequence alone is not capable of eliciting a delayed-type allergic reaction as visualized by skin testing. That the synthetic heptapeptide was recognized, at least in part, as an antigen of mycobacterial origin was shown by the early weak allergic reaction which developed upon its administration to BCG-infected mice. The results of radioimmunoassays confirmed this conclusion.

The antibodies raised against the synthetic heptapeptide conjugated through its $\mathrm{N}$-terminal $\alpha$-amine to BSA were strongly directed to the Cterminal end of the peptide. The $\mathrm{N}$-terminal tetrapeptide had no effect on the radioimmunoassays in the range studied, and the heptapeptide after tryptic digestion, lacking the $\mathrm{C}$-terminal leucine residue, retained only $6 \%$ potency of the undigested peptide in displacing the ${ }^{125} \mathrm{I}$ label. The cross-reaction of PPD with the heptapeptide in radioimmunoassays, although very weak, showed that PPD must contain an antigen representing at least the C-terminal portion of the synthetic peptide. 


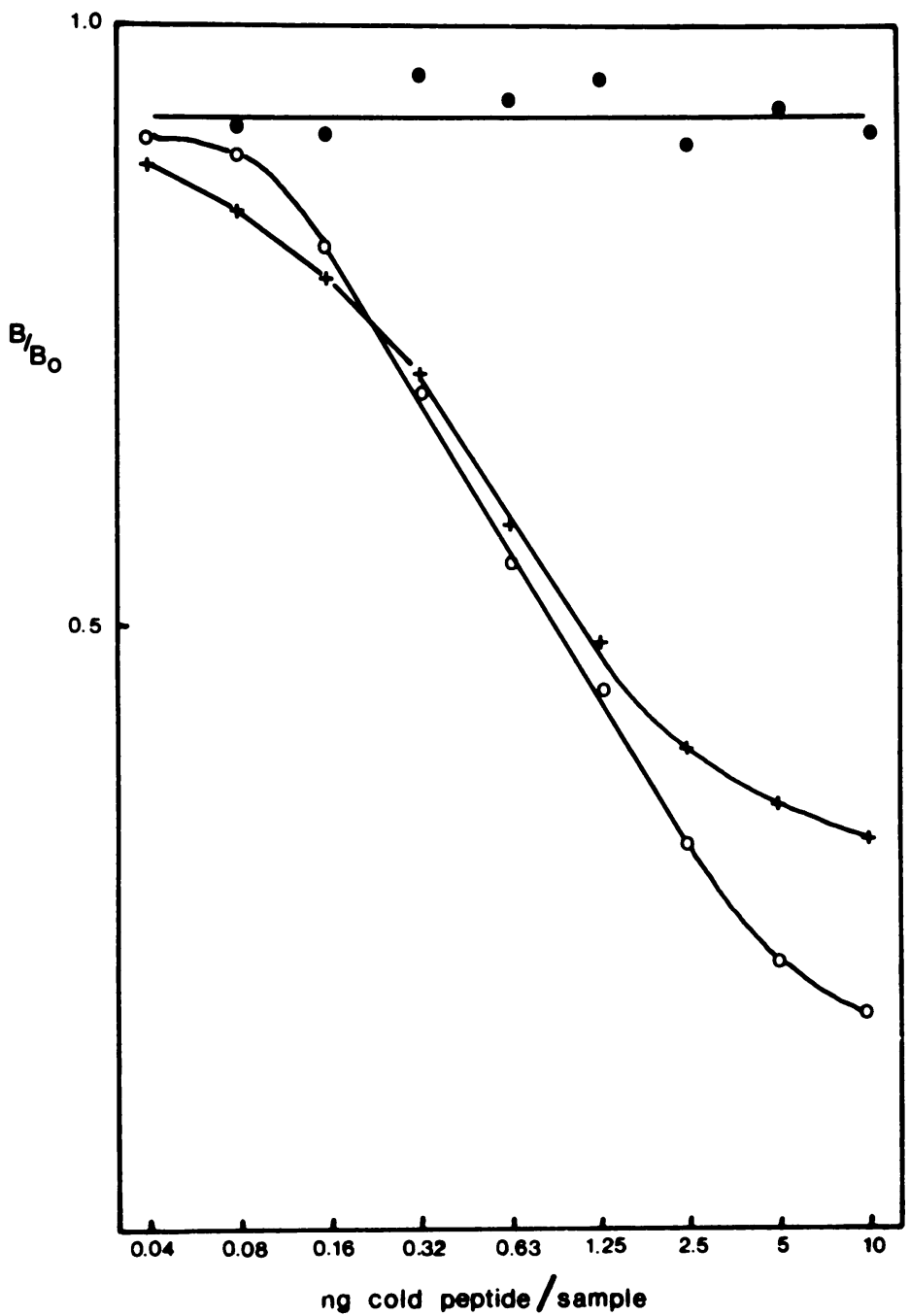

FIG. 1. Inhibition of binding of ${ }^{125}$ I-labeled heptapeptide to its antiserum by unlabeled heptapeptide (O), unlabeled $C$-terminal pentapeptide $(+)$, and unlabeled $N$-terminal tetrapeptide $(O) . B$, Fraction of bound ${ }^{125} I$ label in the presence of unlabeled peptide; $B_{0}$, fraction of bound ${ }^{125}$ I label in the absence of unlabeled peptide.

It is not possible with these results to pinpoint the reasons for the discrepancy between the findings presented in this paper and those reported by Kuwabara $(11,12)$. The lack of tuberculin activity of the heptapeptide might be due to an undetected, unsought for fault in the synthetic peptide or a partially incorrect sequence determination. It might also be that the observed residual tuberculin activity. was wrongly attributed to the tryptic hexapeptide. Indeed, residual tuberculin activity $\left(10^{3}\right.$ to $10^{4}$ less than that of the original protein) was attributed by Kuwabara to the tryptic hexapeptide called T6 (12) and to another tryptic nonapeptide (Mitsui Pharmaceuticals Inc., Tokyo, Japan, Austrian patent 325.769/C1.A6IK, 10 November 1975, application 5646/73; Chem. Abstr. 84:162906m, 1976) which cannot be other than the one called T5. These two peptides were eluted from a Dowex 50-X2 column as two close peaks.

PPD is a product obtained from the materials excreted by tubercle bacilli into the culture medium at a time of bacterial growth when some lysis has already occurred. Thus, one would expect to find some of the intracellular proteins or their fragments in PPD. The observed crossreaction in radioimmunoassays between PPD and the synthetic heptapeptide shows that the protein isolated by Kuwabara, or its fragments, is present in PPD. However, these results are 
Hg PPD/sample

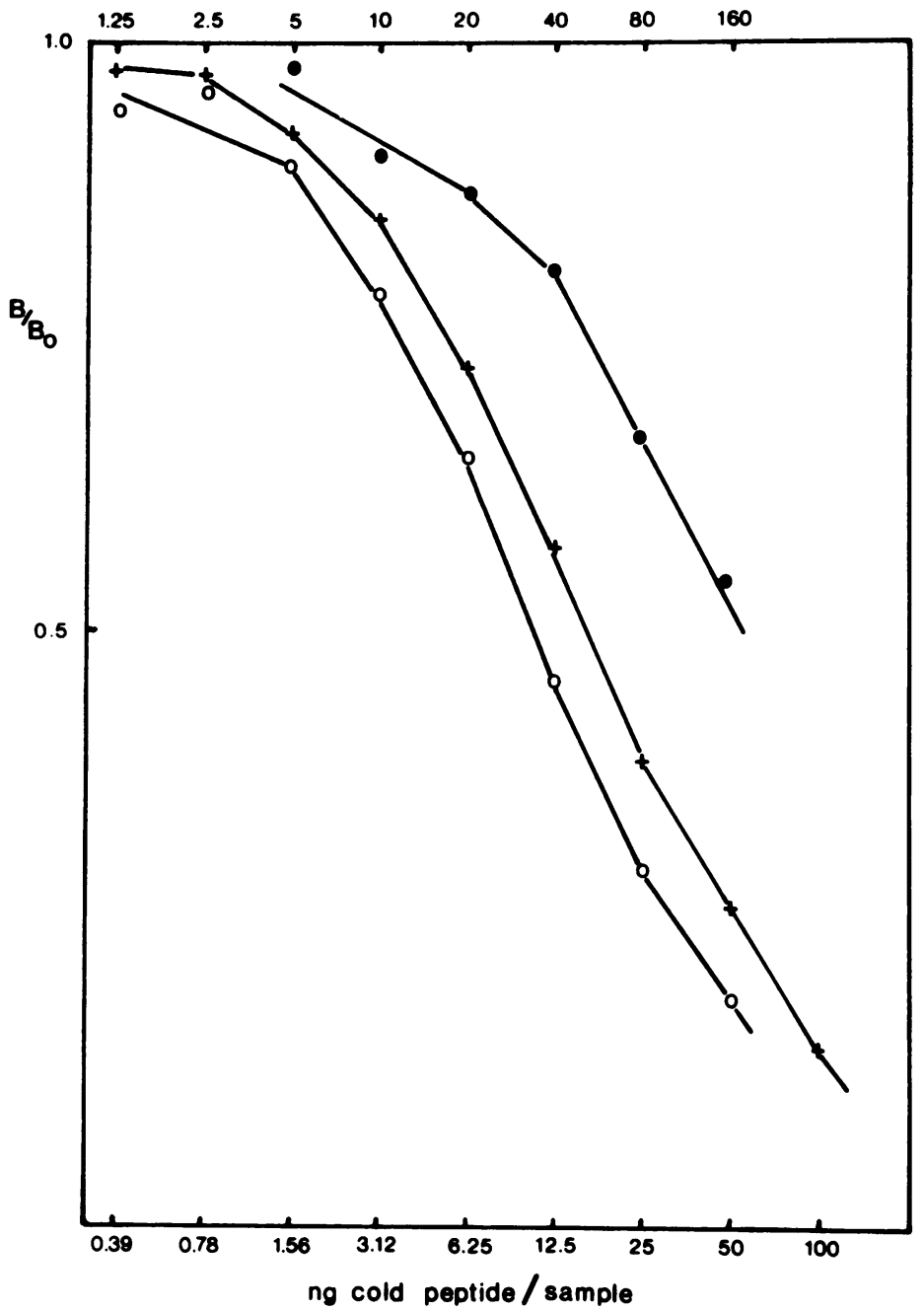

Fig. 2. Inhibition of binding of ${ }^{12 \overline{5}} I$-labeled heptapeptide to its antiserum by unlabeled hexapeptide (+; nanograms), PPD (O; micrograms), and trypsin-digested PPD (O; micrograms). B, Fraction of bound ${ }^{125} I$ label in the presence of unlabeled peptide or PPD; $B_{0}$, fraction of bound ${ }^{125}$ I label in the absence of unlabeled peptide or PPD.

only qualitative and are insufficient to give an indication of the extent of this presence. If the same association constant is assumed for the heptapeptide and the cross-reacting antigen in PPD by the antibodies, then the sequence of the synthetic peptide is represented on a molecular basis to an extent of only $0.03 \%$, the average molecular weight of PPD being 10,000 (16). This situation is unlikely because the immunoreactive determinant measured by the radioimmunoassay would be expected to be in a different environment in PPD than in the synthetic peptide. The value of $0.03 \%$, therefore, is to be considered the lower limit of the presence of Kuwabara's tuberculin-active protein in PPD.

In a further attempt to elucidate some of these questions we are now synthesizing the tryptic nonapeptide designated by Kuwabara as fragment T5 (12).

\section{ACKNOWLEDGMENTS}

This work was supported by grant 78.7.0584 from the Délégation Générale à la Recherche Scientifique et Technique.

I am indebted to H. L. David for continued advice and encouragement, to J. Augier and P. Lagrange for carrying out the biological assays of the synthetic peptide, to J. Van Riet- 
schoten for hydrogen fluoride deprotection of the fully protected heptapeptide, and to C. Gros and C. Rouvot for guidance in the radioimmunoassays. The amino acid analyses were carried out by B. Keil and D. Blanot and their assistance is gratefully acknowledged.

\section{LTTERATURE CITED}

1. Augier, J., and S. Augier-Gibory. 1969. Analyse par focalisation isoélectrique en gel de polyacrylamide des fractions protéiques présentes dans les purified protein derivatives (PPD). Ann. Inst. Pasteur Paris 117:768777.

2. Bodanszky, M., and J. T. Sheehan. 1960. Lactam formation from benzyloxycarbonyl-nitroarginine. Chem. Ind., p.1268-1269.

3. Bolton, A. E., and W. M. Hunter. 1973. The labeling of proteins to high specific radioactivities by conjugation to a ${ }^{125}$ I-containing acylating agent. Biochem. J. 133: 529-539.

4. Edwards, L. B., L. Hopwood, L. F. Affronti, and C. E. Palmer. 1962. Sensitivity profiles of mycobacterial infection. Bull. Int. Union Tuberc. 32:384-394.

5. Ellouz, F., A. Adam, R. Ciorbaru, and E. Lederer. 1974. Minimal structural requirements for adjuvant activity of bacterial peptidoglycan derivatives. Biochem. Biophys. Res. Commun. 69:1317-1325.

6. Graf, L., S. Bajusz, A. Patthy, E. Barat, and G. Cseh. 1971. Revised amide location for porcine and human Adrenocorticotropic hormone. Acta Biochim. Biophys. Acad. Sci. Hung. 6:415-418.

7. Guttmann, S., and R. A. Boiseonnas. 1958. Synthèse du N-acétyl-L-séryl-L-tyrosyl-L-séryl-L-méthionyl- $\gamma$-Lglutamate de benzyle et de peptides apparentés. Helv. Chim. Acta 41:1852-1867.

8. Hirs, C. H. W. 1967. Detection of peptides by chemical methods. Methods Enzymol. 11:325-329.

9. König, W., and R. Geiger. 1970. Eine neue Methode zur Synthese von Peptiden: Aktivierung der Carboxylgruppe mit Dicyclohexylcarbodiimid unter Zusatz von 1-Hydroxy-benzotriazolen. Chem. Ber. 103: 788-798.

10. Kuromizu, $K$., and J. Meienhofer. 1974. Removal of the $\mathbf{N}^{\alpha}$-benzyloxycarbonyl group from cystein-containing peptides by catalytic hydrogenolysis in liquid ammonia, exemplified by a synthesis of oxytocin. J. Am. Chem. Soc. 96:4978-4981.

11. Kuwabara, S. 1975. Purification and properties of tuberculin-active protein from Mycobacterium tuberculosis. J. Biol. Chem. 250:2556-2562.

12. Kuwabara, S. 1975. Amino acid sequence of tuberculinactive protein from Mycobacterium tuberculosis. J. Biol. Chem. 250: 2563-2568.

13. Offord, R. E. 1966. Electrophoretic mobilities of peptides on paper and their use in the determination of amide groups. Nature (London) 211:591-593.

14. Pless, J., and W. Bauer. 1973. Boron Tris(trifluoroacetate) for removal of protecting groups in peptide chemistry. Angew. Chem. Int. Ed. 12:147-148.

15. Sakakibara, S., and Y. Shimonishi. 1965. New method for releasing oxytocin from fully-protected nonapeptides using anhydrous hydrogen fluoride. Bull. Chem. Soc. Jpn. 38: 1412-1413.

16. Seibert, F. B., and J. T. Glenn. 1941. Tuberculin purified protein derivative. Am. Rev. Tuberc. 44:9-25.

17. Shin, K. H., S. Sakakibara, W. Schneider, and G. P. Hess. 1962. The N,O peptidyl shift in anhydrous hydrogen fluoride. Biochem. Biophys. Res. Commun. 8:288293.

18. Von Arx, E., M. Faupel, and M. Brugger. 1976. Eine Modifikation der Chlor-o-Tolidin Farbereaktion für Dünnschichtchromatographie. J. Chromatogr. 120: 224-228. 